\title{
On the Environmental and Economic Problems of Russian Mineral Extracting Clusters
}

\author{
Vera Prusova ${ }^{1,{ }^{*}, \text { Vera }}$ Beznovskaya $^{1}$, and Irina Politkovskaya ${ }^{1}$ \\ ${ }^{1}$ Moscow Automobile and Road Construction State Technical University (MADI), 125319 \\ Leningradsky prospect 64, Moscow, Russia
}

\begin{abstract}
The specialists in subsoil resources refer the mining sector to primary industries and consider it the basis of the extractive industry. Its structure includes the branches engaged in extraction, processing and enrichment of ore, nonmetallic and fuel minerals. The authors analyze the current problems of mining regions in Russia, substantiate the need for new approaches to the processes of resource-and-industrial and innovative development. They identify mechanisms for increasing the efficiency of labor resources use, conclude that the state regulation of the country's mineral and raw materials complex is aimed at increasing the share of deep processing in export and reduction of import dependence.
\end{abstract}

\section{Introduction}

The mining industry of Russia is one of the key drivers in the development of the country's economy, which accounts for $1 / 5$ of the total world mineral and raw materials potential [6]. The federal budget of the Russian Federation annually receives almost half of the total amount of revenues coming to the budget from the tax on extraction of minerals, export customs duties and payments for the use of subsoil: exploration and extractive industries provide $30 \%$ of GDP and $50 \%$ of exports.

\section{Materials and Methods}

The share of products of the mineral and raw materials complex reaches $80 \%$ in export. Export of oil produced in the country is $41-45 \%$, oil products $-30-35 \%$, gas $-30-33 \%$, iron ore $-25 \%$, as well as tungsten, lead raw materials, non-ferrous metals, platinum group metals and diamonds (Tables 1-2) [1-3].

The Russian Federation occupies the leading world positions in the extraction of minerals [4]. However, it should be noted that the quality of the reserves of the mineral and raw materials complex in Russia is much lower than that of the rival countries. For example, in total amount of iron ore reserves, Russia ranks the first in the world. Their composition is less than $9 \%$ of rich, with an iron content of about $60 \%$. In Australia, Brazil and China, such ores constitute up to two thirds of their active reserves.

${ }^{*}$ Corresponding author: info@madi.ru 
Table 1. The segmentation of export of mining products from Russia in 2016.

\begin{tabular}{|l|c|c|}
\hline \multicolumn{1}{|c|}{ Product } & $\begin{array}{c}\text { Export costs, } \\
\text { thousand USD }\end{array}$ & $\begin{array}{c}\text { Export volume, } \\
\text { tons }\end{array}$ \\
\hline Total & 121298188 & 473990258 \\
\hline Mineral oil & 73676262 & 254767395 \\
\hline Petroleum gas & 35344315 & 15744575 \\
\hline Coal & 9074402 & 171400819 \\
\hline Ore & 1949756 & 19615387 \\
\hline Other minerals & 422031 & 2931426 \\
\hline
\end{tabular}

Table 2. The main importers of "mineral products" from the Russian Federation in 2016.

\begin{tabular}{|l|c|c|}
\hline Country & Export costs, billion USD & Share, \% \\
\hline Netherlands & 23.8 & 17.7 \\
\hline China & 18.0 & 13.4 \\
\hline Germany & 8.46 & 6.3 \\
\hline South Korea & 7.49 & 5.6 \\
\hline Japan & 7.07 & 5.2 \\
\hline Italy & 6.64 & 4.9 \\
\hline Poland & 5.9 & 4.4 \\
\hline Belarus & 4.67 & 3.5 \\
\hline Finland & 3.86 & 2.9 \\
\hline Turkey & 3.75 & 2.8 \\
\hline Total & 134.9 & 100 \\
\hline
\end{tabular}

According to the reserves of copper raw materials, Russia is on the third place in the world rating, but rich deposits have already been developed. The reserves of tin ores in the Russian Federation are in two-three times worse for the quality than Indonesian, Malaysian and Brazilian deposits. Despite the first and third place in the reserves of zinc and lead ores, their quality is in two-three times lower than the reserves of similar ores from Australia and Canada.

In Russia, there are the largest reserves of titanium ores, but due to the extremely low content of metal, our country is an importer of titanium. A similar situation may be observed for other minerals. Not all mineral resources in Russia are of poor quality, there are exceptions: Norilsk deposits of poly-metallic ores containing nickel, copper, cobalt, gold, silver, platinum group metals. As a result, there is an intensive development of these deposits: $20 \%$ of the world's raw materials for the production of nickel, more than $10 \%$ of cobalt, more than $3 \%$ of copper and other valuable products.

Another problem of mining industry in the Russian Federation is the lack of systematic geological exploration. To solve it, a set of scientific, technical, economic and social measures should be introduced into the production sector (since 1966 there has been no government projects in this direction in the Russian Federation). Most open and known deposits are on the verge of exhaustion. In addition, there is a problem of abandoned deposits, for the restoration and development of which there is no investment. For example, the Udokan copper deposit contains about 200 tons of raw materials, but nobody develops it. Other large deposits (Oktyabrskoye, Gaiskoye, Talnakhskoye - where reserves are coming to an end) are also under development. A similar situation is observed in the gold mining industry. 


\section{Results and Discussion}

At present, investors are interested in prompt returns with minimal risks [5-7]. As exploration is primarily carried out by young enterprises, it is difficult for them to attract investors for further financing in the implementation of projects. According to actual data, the share of expenditures for the exploration of new reserves decreased to $30 \%$, the share of expenses for operational exploration is $31 \%$.

Serious environmental problems arise in the development of deposits by mining, open and bore-hole methods: air pollution by dust and gas emissions; violation of the landscape; contamination of soil, mineral resources, and water. Mining even with the most ecological use of resources causes irreversible changes in the natural environment due to the impossibility of its restoration to the original level.

Using mining method, the negative consequences are associated with the formation of dumps and the lowering of the groundwater level. Open method is considered the most progressive and is used for the extraction of solid mineral resources. Problems arise during the development of quarries and cuts that disturb the earth cover. The bore-hole method is used for the extraction of liquid and gaseous mineral. The environmental problems of such mining are related to the fact that the deepest layers of the earth are affected. It should be noted that most mining enterprises have out of date purification facilities, as a result of their inefficient operations the surrounding world is adversely affected. Equipping production facilities with modern specialized machinery, with which pollution will be prevented, requires government funding for mining enterprises [8-10].

An inefficient personnel policy is being implemented in the mining industry. The romance of geologists, miners, oil workers is far in the past. There is a constant shortage of specialists, starting with middle-level specialists and ending with top-level managers. In our opinion, experienced specialists in the mining industry should be regarded as a valuable asset. To achieve that, it is necessary to restore targeted agreements for the training of specialists by colleges and universities; to provide young employees with the help of a supervisor in his working place; constantly analyze the HR strategy for its effectiveness.

In recent years, another problem has arisen in the mining sector of economy - a lack of innovations. First of all, innovations should increase labor productivity. In the period of high prices an increase in production was in the forefront, but not productivity. Increase in productivity will allow receiving long-term economic effect. The problem of increasing the labor productivity must be solved in a complex manner, considering each structural component in the unity of the entire organizational structure, changes in the corporate culture, and conducting regular analytical work. To solve the given problem is possible through the introduction of innovations [5]. For some companies, innovations will simply help to survive, for others it is a step towards higher profits, higher labor productivity and more profitable economic positions in the market. At present, mining and metallurgical companies spend $90 \%$ less (as a percentage of revenues) for the introduction of new technologies than oil producing enterprises. This once again confirms the fact that there is a wide field for innovation in the mining industry.

The creation of technology parks should be considered as one of the possible options of breakthrough innovations. Techno-park is an intermediary structure between researchers, developers and companies that need new technological developments. The forms of organizing techno-parks depend on the nature and scope of their functions: innovation centers, scientific and research parks, technology parks, technology centers, conglomerates of technological and scientific parks.

It would be wrong to assume that techno-parks in the mining industry have not been created by now. There is an experience of creating an industrial park in Kuzbass. The main development directions of JSC "Kuzbass Technopark" for 2010-2017 are given in Table 3. 
Table 3. The main directions of development of JSC "Kuzbass Technopark" for 2007-2017.

\begin{tabular}{|c|c|}
\hline Direction & Content \\
\hline $\begin{array}{l}\text { Industry } \\
\text { specialization }\end{array}$ & $\begin{array}{l}\text { - coal mining, processing, power engineering, engineering, processing of } \\
\text { ore and non-metallic minerals, ecology, medicine, biotechnology, security, } \\
\text { information technology, education }\end{array}$ \\
\hline $\begin{array}{l}\text { The } \\
\text { infrastructure } \\
\text { of the } \\
\text { technopark } \\
\text { site in } \\
\text { Rudnichny } \\
\text { district of } \\
\text { Kemerovo } \\
\text { city }\end{array}$ & $\begin{array}{l}\text { - the business incubator, the production and laboratory building "Ecology } \\
\text { and Nature Management" were built on the technopark site (10.7 hectares); } \\
\text { - new projects are implemented with the involvement of private investors: } \\
\text { the building "Medicine and Biotechnology", "Industrial Safety"; } \\
\text { - the conference facilities and event areas of the technopark: a conference } \\
\text { hall for } 150 \text { seats; hall for interactive events for } 150 \text { seats; conference } \\
\text { rooms, meeting rooms, computerized classrooms, small rooms for } \\
\text { presentations (more than } 10 \text { venues can be used at a time, hosting up to } 300 \\
\text { participants); } \\
\text { - on the site of Kuzbass technopark there are the Agency for Attraction and } \\
\text { Protection of Investments of the Kemerovo Region, the Kuzbass Chamber } \\
\text { of Commerce and Industry, the Polygraphic Center, the Regional } \\
\text { Engineering Center, and the Cluster Development Center. }\end{array}$ \\
\hline Project work & $\begin{array}{l}\text { - } 60 \text { resident companies implementing innovative projects received the } \\
\text { support, of which } 21 \text { residents were located on the territory of the techno- } \\
\text { park; } \\
\text { - more than } 356 \text { applications for support were considered, } 173 \text { innovative } \\
\text { projects were adopted by the Expert Council, } 53 \text { projects received regional } \\
\text { tax incentives; } \\
\text { - in } 2016 \text { the investments in the development of projects of resident } \\
\text { companies amounted to } 2.5 \text { billion rubles, capital investments - } 2.1 \text { billion } \\
\text { rubles, revenues - } 2.3 \text { billion rubles., The number of employees in resident } \\
\text { companies - } 1061 \text { people, tax deductions - } 399 \text { million rubles; } \\
\text { - the total investment volume of resident companies for } 2010-2016 \\
\text { amounted to } 11 \text { billion rubles., the volume of capital investments }-8.7 \\
\text { billion rubles. }\end{array}$ \\
\hline $\begin{array}{l}\text { Modification } \\
\text { of the } \\
\text { activities of } \\
\text { the } \\
\text { Technopark } \\
01 / 01 / 2017 \text {. }\end{array}$ & $\begin{array}{l}\text { - "Regional Integrated Center", "Center for Cluster Development" were } \\
\text { excluded from the Techno-park and the management functions of } 2 \text { clusters } \\
\text { were removed; } \\
\text { - functions of the regional representative of the Bortnik fund, functions of } \\
\text { the regional representative in the Council of the interregional program } \\
\text { "Siberian Biotechnology Initiative" were removed; } \\
\text { - the financial function to promote the development of innovations has } \\
\text { been minimized and is not included in the regional program of the } \\
\text { technopark for 2017; } \\
\text { - the function of the regional development institute was removed, since the } \\
\text { Department of Investments and Strategic Development had not signed an } \\
\text { agreement with the Techno-park; } \\
\text { - Techno-park has been transferred to the self-repayment model; } \\
\text { - the financial accounting methodology was developed: monthly budgeting } \\
\text { of cash flows, the register of obligations and payments, the adjustment of } \\
\text { accounting and tax registration. }\end{array}$ \\
\hline
\end{tabular}

In 2017, the income of JSC Kuzbass Techno-park (rent, payment for consulting services, project support, and regional subsidy for the Central Committee) amounted to 27.3 million rubles, while maintenance and management costs - 36.9 million rubles. Consequently, every month Techno-park generates losses of 1 million rubles.

Analysis of the financial model of JSC "Kuzbass Techno-park" showed that its activity in 2010-2017 was not effective from the profit making point of view of. New technologies and innovative developments were not introduced at the mining companies of the 
Kemerovo region. However, funds for resource-and-industrial and innovative development of the region are provided. The investments in mining enterprises of Kuzbass are given in Table 4 [1-3].

Table 4. The investments in mining enterprises of Kuzbass, billion rubles.

\begin{tabular}{|l|c|}
\hline \multicolumn{1}{|c|}{ Mining enterprise } & $\begin{array}{c}\text { The volume of } \\
\text { investments }\end{array}$ \\
\hline $\begin{array}{l}\text { The development of "Bereznyakovskoye" field in the } \\
\text { Southern Urals }\end{array}$ & 4.5 \\
\hline $\begin{array}{l}\text { The construction of "Butovskaya" mine and related } \\
\text { infrastructure in Kemerovo }\end{array}$ & 8.8 \\
\hline $\begin{array}{l}\text { The construction of mining and processing plant "White } \\
\text { Mountain" in the Khabarovsk Territory }\end{array}$ & 5.6 \\
\hline $\begin{array}{l}\text { The construction of "Kaskad-2" factory of Kuzbass Fuel } \\
\text { Company }\end{array}$ & 4.9 \\
\hline $\begin{array}{l}\text { The construction of mining and processing plant in the } \\
\text { Mogochinsky district of the Trans-Baikal Territory }\end{array}$ & 2.2 \\
\hline $\begin{array}{l}\text { The construction of enriching factory second block at the } \\
\text { mine named after S.M. Kirov OJSC "SUEK-Kuzbass" in } \\
\text { Leninsk-Kuznetsk in the Kemerovo region }\end{array}$ & 2.5 \\
\hline
\end{tabular}

The authors consider that the solution of innovation problems should be found through the creation of the interaction system among the state, business, science and education namely, the development of clusters [5]. In economic terms, the cluster is the spatial partnership, joint innovation program, the introduction of new industrial, financial, engineering, management techniques in order to improve productivity, efficiency, and competitiveness of its members, based on the interaction of government, business and society.

One of the promising deposits in the Russian Federation is Elginskoye field (the Republic of Sakha (Yakutia)). The deposit, the area of which is 246 square $\mathrm{km}$, is a flat, asymmetric brachyfold. The main coal seams are confined to the deposits of Neryungri and Undiktanskaya strata. Most of the coal resources are concentrated in four strata of a complex structure, which overlap with deposits of low power, which is very advantageous for the organization of open-pit mining. Elginsky coal can be enriched to the highest world standards and turned into the export coking coal of high quality.

It is also worth noting that the optimal option for the development of mining projects in Russia is the process of integration of companies, scientific centers and the state. The construction and operation project of a mining and processing plant at the Drazhnoe deposit in Yakutia (the license belongs to Vysochaishy) is an example of obtaining a synergistic effect. According to the construction plans of the region the first phase of the project with the capacity of 700 thousand tons of ore per year will be launched in 2018. In addition, LLC "Boguslavets" is currently conducting geological exploration of the Malo-Taryn gold deposit. For the facility building the state support was required for the reconstruction of the Kolyma-Nelkan-Drezhny motorway, $105 \mathrm{~km}$ long, with transfer for year-round operation. The cost of the project was 638 million rubles. Republican authorities plan to create on the basis of Drazhnoe deposit a Processing Center for complex component ores and concentrates and establish the territory of advanced social and economic development (TASED) with the participation of young scientists from specialized educational institutions.

The interaction of government, business and society within the framework of the regional clusters model gives each of the participants certain advantages. For the society they are jobs, increasing well-being, economic stability, solving social problems through 
financing from budgets of different levels: from municipal to federal. For the government they are an increase in taxpayers, replenishment of budgets. For business - to expand opportunities for modernization, reduce costs, improve labor productivity and product competitiveness.

\section{Conclusion}

The economy of the Russian Federation, including mining industry, operates under economic and financial sanctions. They damage mining and metallurgical companies that carry out international activities and supply raw materials to foreign markets.

Summarizing, it should be emphasized that in order to maintain a stable level of profitability, reduce costs, increase productivity and get the maximum revenue in mining industry, we must rely on cluster and innovative development of industry.

\section{References}

1. Rosstat, Import and Export (RS, Moscow, 2017)

2. Rosstat, Macroeconomic Statistics (RS, Moscow, 2017)

3. Rosstat, National Accounts (RS, Moscow, 2017)

4. M. Cehlár, P. Varga, Z. Jurkasová, M. Pašková, Acta Montanistica Slovaca, 15:2, 132138 (2011)

5. M. Cehlár, J. Janočko, Z. Šimková, T. Pavlik, E3S Web of Conf., 15, 01019 (2017)

6. V. Frolova, O. Dolina, T. Shpil'kina, E3S Web Conf., 21, 04018 (2017)

7. E. Dotsenko, N. Ezdina, E3S Web of Conf., 15, 04012 (2017)

8. S.A. Zhironkin, , Ugol', 6, 62-63 (2001)

9. S.A. Zhironkin, Ugol', 4, 47-49 (2002)

10. M.A. Tyulenev, S.A. Zhironkin, O.I. Litvin, E.A. Tyuleneva, O.V. Zhironkina, S.O. Markov, Geotech. Geol. Eng. 35:5, 2065-2077 (2017) 